\title{
PENGARUH EDUKASI METODE CBIA TERHADAP TINGKAT PENGETAHUAN SWAMEDIKASI PENYAKIT JAMUR KULIT
}

\author{
Rizka Nur Sabila ${ }^{1}$, Yulian Wahyu Permadi ${ }^{2}$, Ainun Muthoharoh ${ }^{3}$, Wulan Agustin \\ Ningrum $^{4}$ \\ ${ }^{1,2,3,4}$ Program Studi Sarjana Farmasi, Fakultas Ilmu Kesehatan, Universitas Muhammadiyah Pekajangan \\ Pekalongan, Indonesia \\ e-mail: 1rizkanursabila31638@gmail.com,2yulian_wahyu_permadi@yahoo.com, \\ 3ainun.muthoharoh@gmail.com ${ }^{4}$ wulan1414@yahoo.co.id
}

\begin{abstract}
ABSTRAK
Penyakit jamur kulit disebabkan karena infeksi jamur, penyakit ini rentan dialami oleh santri di Pondok Pesantren karena faktor lingkungan maupun gaya hidup yang tidak bersih dan dapat mengganggu aktivitas sehingga harus diobati. Penggunaan obat antijamur yang sering digunakan bebas karena keterbatasan pengetahuan dalam pelaksanaan swamedikasi, sehingga perlu diberikan edukasi supaya pengobatannya tepat. Penelitian ini bertujuan untuk mengetahui pengaruh edukasi leaflet dengan metode CBIA terhadap tingkat pengetahuan swamedikasi penyakit jamur kulit pada santriwati. Penelitian ini menggunakan metode prospektif dengan desain quasy experimental tipe one group pretest-postest with control group. Jumlah sampel penelitian sebanyak 66 santriwati dibagi menjadi dua kelompok. Hasil tingkat pengetahuan santriwati sebelum diberikan edukasi masuk dalam kategori baik sebesar 89,4\% dan tingkat pengetahuan sesudah diberikan edukasi masuk dalam kategori baik sebesar 96,97\%. Dari data yang diperoleh terdapat pengaruh edukasi dengan metode CBIA terhadap tingkat pengetahuan swamedikasi penyakit jamur kulit pada santriwati Pondok Pesantren Al-Mubarok dikarenakan pada uji mann-whitney nilai p-value $0,000<0,05$
\end{abstract}

Kata kunci: CBIA, Jamur kulit, Pengetahuan, Swamedikasi.

\begin{abstract}
Skin fungal disease is caused by a fungal infection, this disease is susceptible to being experienced by students in Islamic boarding schools due to environmental factors and an unclean lifestyle and can interfere with activities so that they must be treated. The use of antifungal drugs are often used freely due to limited knowledge in the implementation of self-medication, so it is necessary to provide education so that the treatment is appropriate. This study aims to determine the effect of leaflet education with the CBIA method on the level of knowledge of self-medication of skin fungal diseases in female students. This study uses a prospective method with a quasi-experimental design type one group pretest-posttest with control group. The number of research samples was 66 female students divided into two groups. The results of the knowledge level of female students before being given education were in the good category of $89.4 \%$ and the level of knowledge after being given education was in the good category of $96.97 \%$. From the data obtained, there is an effect of education using the CBIA method on the level of knowledge of self-medication of skin fungal diseases in Al-Mubarok Islamic Boarding School students because the Mann-Whitney test has a p-value of $0.000<0.05$.
\end{abstract}

Keywords: CBIA, skin fungus, knowledge, self-medication

\section{PENDAHULUAN}

Infeksi jamur kulit sering dijumpai di daerah tropis yang disebabkan oleh udara yang lembab sehingga keadaan tersebut dapat mendukung berkembangnya penyakit jamur kulit [1]. Keadaan sosial ekonomi bisa menjadi faktor penyebab terjadinya penyakit jamur selain karena faktor kelembapan lingkungan, faktor lain yang mempengaruhi biasanya karena gaya hidup bersih dan sehat dari diri sendiri. Kondisi kulit yang disebabkan oleh infeksi jamur adalah Tinea manus et pedis, Tinea unguinum, Tinea imbrikata dan Tinea corporis [2]. 
Penyakit jamur kulit yang dialami masyarakat maupun santri, akan mendorong mereka supaya melakukan respon terhadap penyakit tersebut. Salah satu responnya apabila merasakan sakit yaitu dengan melakukan tindakan pengobatan sendiri atau swamedikasi [3]. Secara umum, swamedikasi adalah upaya pengobatan sendiri dengan pengobatan, pengobatan tradisional, atau cara lain tanpa nasihat dari tenaga kesehatan. Dalam upaya memelihara kesehatan yang baik, swamedikasi merupakan upaya masyarakat untuk mengatasi penyakit kesehatannya, karena perannya tidak boleh diabaikan [4].

Pengobatan sendiri dapat terjadi ketika mendapatkan obat tanpa resep dokter, pemberian dari teman atau keluarga, dan membelinya berdasarkan resep sebelumnya atau menggunakan obat sisa. Kebanyakan orang menganggap pengobatan sendiri lebih praktis karena lebih praktis untuk mengobati penyakit ringan dalam kehidupan sehari-hari [5]. Berdasarkan hasil Survei Sosial Ekonomi Nasional tahun 2014, proporsi penduduk yang berobat atau berobat sendiri untuk status kesehatan ditunjukkan sebesar $61,05 \%$. Hal ini menunjukkan bahwa perilaku pengobatan sendiri di Indonesia masih cukup tinggi [6]. Tingginya tingkat swamedikasi disebabkan oleh perkembangan teknologi informasi melalui internet dan biaya mengunjungi dokter tinggi atau tidak cukup waktu untuk berobat [7].

Berdasarkan swamedikasi yang banyak dilakukan di masyarakat, untuk mengatasi ketidaktepatan dalam swamedikasi perlu pengetahuan yang baik. Sehingga perlu dilakukan pemberian edukasi kesehatan. Edukasi kesehatan bertujuan untuk memperluas pengetahuan dan keterampilan seseorang melalui pembelajaran keterampilan dan pengajaran sehingga individu atau kelompok dapat mengubah dan mempengaruhi perilaku manusia. Metode edukasi yang digunakan dalam meningkatkan pengetahuan swamedikasi menggunakan metode Community Based Interactive Approach (CBIA) dimana metode ini efektif mampu untuk meningkatkan pengetahuan dalam swamedikasi. Berdasarkan hal tersebut, dengan melihat banyaknya masyarakat yang melakukan swamedikasi Peneliti tertarik untuk melakukan penelitian mengenai pengaruh edukasi leaflet menggunakan metode CBIA terhadap jamur kulit pada santriwati Pondok Pesantren AlMubarok Medono Pekalongan. Pemberian metode CBIA ini diharapkan mampu meningkatkan pengetahuan santriwati dalam melakukan swamedikasi.

\section{METODE PENELITIAN}

\subsection{Alat dan Bahan}

Alat ukur untuk instrumen penelitian yang digunakan oleh peneliti adalah kuesioner pretest dan postest. Kuesioner merupakan teknik pengumpulan data yang dilakukan dengan cara memberikan seperangkat pertanyaan maupun pernyataan tertulis kepada responden untuk kemudian dijawab [8]. Kuesioner yang digunakan yaitu kuesioner tertutup dan diukur menggunakan skala Guttman sehingga diperoleh jawaban yang pasti "Benar" atau "Salah". Lembar Informed concern serta leaflet dan contoh obat anti jamur sebagai alat peraga dalam edukasi CBIA.

\subsection{Jalannya Penelitian}

\subsubsection{Uji Validitas dan Reabilitas}

Salah satu alat yang digunakan dalam survei ini adalah kuesioner. Oleh karena itu, untuk memperoleh data yang valid dan reliabel, sebaiknya dilakukan uji validitas dan reliabilitas kuesioner sebelum melakukan survei.Pelaksanaan uji validitas dan reabilitas dilaksanakan pada responden yang tidak menjadi sampel dalam penelitian sebanyak 30 santriwati di Pondok Nurul Huda. Pengujian validitas menggunakan uji korelasi product moment. Dimana dapat dilihat dari tabel koefisien korelasi bahwa $r$ tabel dengan taraf signifikasi 5\% dengan jumlah 30 responden menggunakan perbandingan $r$ tabel 0,361 atau bisa juga dengan melihat nilai sig < 0,05. Cara pengambilan keputusan pada uji validitas yaitu jika $r$ hitung $>r$ tabel, maka item pernyataan dapat dikatakan valid. Berdasarkan hasil validitas menunjukkan 30 butir pernyataan yang valid.

Setelah diuji validitas, kemudian dilakukan uji reabilitas dengan tujuan untuk 
menunjukkan sejauh mana item pernyataan pada instrumen penelitian itu dapat diandalkan dan dipercaya serta konsisten bila dilakukan pengukuran berulang-ulang menggunakan analisis statistik dengan aplikasi SPSS versi 16, data yang digunakan adalah data yang telah valid. Pada uji reabilitas penelitian ini menggunakan uji nilai crobach alpha. Kuisioner dikatakan reliable jika alpha minimal 0,60 [9]. Berdasarkan hasil uji reabilitas didapatkan nilai Cronbach's Alpha sebesar 0,903 (>0,6) maka dapat dikatakan reliabel.

\subsubsection{Tahap Pertama}

Peneliti membuat memo untuk diberikan ke LPPM perihal studi pendahuluan dan ditandatangani oleh koordinator skripsi di kantor program studi Sarjana Farmasi, peneliti mengurus surat izin pengumpulan data pada bagian LPPM Universitas Muhammadiyah Pekajangan Pekalongan, peneliti mengurus surat perizinan penelitian yang diserahkan ke Pondok Pesantren Al-Mubarok Medono Pekalongan.

\subsubsection{Tahap kedua}

Tahap penelusuran dan pengambilan data. Hari pertama dilakukan pembagian lembar informed cornsent dan data karakteristik responden pada kelompok kontrol dan kelompok perlakuan Pretest diberikan terlebih dahulu sebelum intervensi, baik kelompok kontrol maupun kelompok perlakuan. Pretest dilakukan secara bergantian. Pada kelompok kontrol terlebih dahulu setelah selesai dilanjutkan dengan kelompok perlakuan yang mengerjakan pretest. Selanjutnya pemberian edukasi leaflet dengan metode CBIA pada kelompok perlakuan yang sudah mengerjakan pretest yang dibagi menjadi 5 kelompok dengan beberapa kelompok kecil terdiri dari 6-7 orang setiap kelompoknya terdapat ketua kelompok yang diberikan leaflet berisi definisi penyakit jamur kulit, gejala, jenis-jenis penyakit jamur kulit dan diberikan satu contoh obat untuk penyakit jamur kulit pada setiap kelompok. Selanjutnya narasumber (peneliti) memberikan penjelasan dan setiap kelompok diminta untuk mengamati dan menelaah contoh obat jamur kulit yang diberikan dari kemasan, brosur, logo obat, zat aktif dan memahami isi dari leaflet setelah itu diminta untuk menuliskan kembali isi dari leaflet dan dari kemasan obat pada lembar kerja yang sudah disediakan sambil berdiskusi kepada narasumber (peneliti) apabila ada yang kurang jelas. Terakhir, perwakilan kelompok diminta untuk memaparkan materi yang sudah dicatat dilembar kerja yang sudah diisi. Satu hari setelah edukasi, dilakukan penilaian posttest baik pada kelompok perlakuan maupun kelompok kontrol.

\subsubsection{Desain Penelitian}

Penelitian ini merupakan jenis penelitian quasy experimental dengan pendekatan one grup pretest postes with control grup. Metode merupakan metode yang digunakan untuk menguji pengaruh sebab akibat. Penelitian ini dengan membandingkan antara kelompok perlakuan dan kelompok kontrol. Menurut Sugiyono (2017)[10], metode ini dapat diartikan sebagai metode penelitian yang digunakan untuk mencari pengaruh dari suatu perlakuan tertentu. Ciri-ciri dari penelitian ini adalah sampel yang digunakan untuk eksperimen maupun kontrol dipilih secara random. Teknik pengambilan sampel dengan simple random sampling.

\subsubsection{Tempat dan Waktu Penelitian}

Penelitian ini dilakukan di Pondok Pesantren Al-Mubarok Medono Pekalongan pada 7-16 Juli 2021.

\subsubsection{Populasi dan Sampel Penelitian}

Populasi adalah keseluruhan unit dalam pengamatan yang akan dilakukan [11]. Populasi dalam penelitian ini yaitu santriwati yang pernah mengalami penyakit jamur kulit di Pondok Pesantren Al-Mubarok Medono Pekalongan yang berjumlah 77 responden. Sampel adalah bagian dari populasi yang ciri-cirinya telah diselidiki ataupun 
diukur.

Adapun besarnya sampel pada penelitian ini dapat dihitung dengan menggunakan rumus Slovin karena populasi sudah diketahui dengan tingkat kesalahan 5\% sebagai berikut:

$$
\begin{aligned}
& \mathbf{n}=\frac{\boldsymbol{N}}{\boldsymbol{N} \cdot \boldsymbol{d}^{2}+\mathbf{1}} \\
& \mathrm{n}=\frac{77}{77 \cdot(0,05)^{2}+1} \\
& \mathrm{n}=\frac{77}{77 \cdot 0,0025+1} \\
& \mathrm{n}=\frac{77}{0,1925+1} \\
& \mathrm{n}=\frac{77}{1,1925} \\
& \mathrm{n}=64,57 \text { dibulatkan menjadi } 66 \text { responden }
\end{aligned}
$$

keterangan: $\mathrm{n}=$ Jumlah sampel

$\mathrm{N}=$ Jumlah populasi $(\mathrm{N}=77)$

$\mathrm{d}^{2}=$ Presisi (ditetapkan tingkat kesalahan 5\% dengan tingkat kepercayaan $95 \%)$

Sampel dalam penelitian ini menggunakan kelompok eksperimen (perlakuan) dan kelompok kontrol (tanpa perlakuan) dengan besar anggota kedua kelompok yang sama yaitu 33 kelompok kontrol dan 33 kelompok eksperimen.

\subsubsection{Cara Pengambilan Sampel}

Untuk mendapatkan data sesuai dengan fokus penelitian ini, maka peneliti menentukan responden dengan kriteria sebagai berikut :

1. Kriteria Inklusi

Kriteria inklusi adalah karakteristik umum subjek penelitian dari suatu populasi suatu target dan terjangkau akan diteliti. Adapun kriteria inklusi sampel penelitian yang akan diteliti adalah sebagai berikut.
a. Santriwati yang bermukim di Pondok Pesantren Al-Mubarok Medono
b. Usia 12-21 Tahun
c. Sedang/pernah melakukan swamedikasi penyakit jamur kulit dalam 3 bulan terakhir
d. Tidak berobat jamur kulit ke dokter
e. Santriwati yang bersedia mengikuti sampai akhir penelitian

2. Kriteria eksklusi

Kriteria eksklusi adalah keadaan yang menyebabkan subjek memenuhi kriteria inklusinamun tidak dapat diikutsertakan dalam penelitian.
a. Santriwati yang tidak bersedia menjadi responden
b. Santriwati yang tidak mengisi kuesioner dengan lengkap.

\subsubsection{Variabel Penelitian}

Variabel penelitian ini terbagi menjadi dua yaitu variabel bebas (independent) dan variabel terikat (dependent). Untuk variabel bebasnya yaitu pemberian edukasi dengan metode CBIA. Sedangkan untuk variabel terikatnya yaitu tingkat pengetahuan swamedikasi penyakit jamur kulit. 


\subsection{Analisis Data}

Data yang telah diperoleh selanjutnya dianalisis. Analisis data dilakukan untuk menunjang pembuktian hipotesis. Proses analisis data dimulai dengan menelaah seluruh data yang diperoleh melalui kuesioner. Langkah - langkah analisis data dilakukan secara bertahap, yaitu :

\subsubsection{Analisis Deskriptif}

Analisis ini bertujuan untuk menjelaskan atau mendeskripsikan karakteristik setiap variabel penelitian. Pada umumnya dalam analisis ini hanya menghasilkan distribusi dan presentase dari setiap variabel. Dimana data yang bersifat kategorik yaitu umur pasien, jenis kelamin, disajikan dalam bentuk frekuensi dan presentase. Semua data dianalisis dengan bantuan software statistik dan disimpulkan secara deskriptif.

\subsubsection{Uji Normalitas}

Uji ini digunakan sebagai syarat untuk mengetahui apakah data terdistribusi normal atau tidak sebelum dianalisis data. Uji ini menggunakan uji one sample Kolmogorov-spironov karena sampel $>50$ orang. Syarat uji ini silai sig $>0,05$ maka data terdistribusi normal dan sebaliknya [12]. Hasil iji normalitas pada penelitian ini data tidak terdistribusi normal maka akan dilanjutkan dengan uji non parametrik.

\subsubsection{Uji Hipotesis}

Data diperoleh tidak normal maka dilanjutkan dengan uji non parametrik yaitu menggunakan uji Wilcoxon signed rank. Pengujian ini menggunakan pretest dan posttest kelompok eksperimen dan kelompok kontrol dengan nilai interpretasi dari uji Wilcoxon signed rank dengan memperhatikan nilai $\mathrm{p}$. apabila nilai $\mathrm{p}<0,05$ maka terdapat perbedaan antara sebelum dan sesudah pemberian intervensi [13]. Selanjutnya dilanjutkan dengan uji Mannwhitney untuk mengetahui perbedaan rata-rata dua sampel yang tidak berpasangan dengan membandingkan posttest kelompok eksperimen dan kelompok kontrol. Syarat uji Mannwhitney dengan melihat nilai $\mathrm{p}$, apabila nilai $\mathrm{p}<0,05$ maka terdapat pengaruh.

\section{HASIL DAN PEMBAHASAN}

\subsection{Karakteristik Responden}

Tabel I. Deskripsi Karakteristik Responden

\begin{tabular}{lcc}
\hline \multicolumn{1}{c}{ Karakteristik responden } & $\begin{array}{c}\text { Frekuensi } \\
(\mathbf{N}=\mathbf{6 6})\end{array}$ & $\begin{array}{c}\text { Persentase } \\
(\mathbf{\%})\end{array}$ \\
\hline Jenis kelamin & & - \\
Laki-laki & - & -100 \\
Perempuan & 66 & \\
\hline Umur (Tahun) & & 24,2 \\
15 & 16 & 18,2 \\
16 & 12 & 16,7 \\
12 & 11 & 12,1 \\
13 & 8 & 12,1 \\
17 & 8 & 4,5 \\
14 & 3 & 4,5 \\
18 & 3 & 3,0 \\
19 & 2 & 3,0 \\
20 & 2 & 1,5 \\
21 & 1 & \\
\hline Pendidikan & & 47,0 \\
MA & 31 & 27,3 \\
SALAF & 18 & \\
\hline
\end{tabular}




\begin{tabular}{lcc}
\hline MTs & 17 & 25,8 \\
\hline Riwayat Penyakit Jamur Kulit & & \\
Kutu Air & 41 & 62,1 \\
Panu & 17 & 25,8 \\
Kadas/Kurap & 8 & 12,1 \\
\hline Obat yang digunakan & 32 & \\
Salep 88® & 14 & 48,5 \\
Kalpanax® & 10 & 21,2 \\
Ultrasilin® & 6 & 15,2 \\
Salep 2-4® & 2 & 9,1 \\
Miconazole Krim & 2 & 3,0 \\
Pagoda Salep® & & 3,0 \\
\hline Tempat Memperoleh Obat & 48 & \\
Apotek & 14 & 72,7 \\
Warung/Toko Klontong & 4 & 21,1 \\
Toko Obat & - & 6,1 \\
Online & & - \\
\hline Sumber Memperoleh Obat & 55 & 83,3 \\
Pengalaman Pribadi dan keluarga & 6 & 9,1 \\
Teman dan Tetangga & 5 & 7,6 \\
Media Massa (televisi, radio, internet) & & \\
\hline
\end{tabular}

Berdasarkan tabel I menunjukkan seluruh responden berjenis kelamin perempuan. Hal ini dikarenakan penelitian yang dilakukan pada santri perempuan saja, sehingga seluruh respondennya adalah perempuan. Menurut Cho [14], menyatakan bahwa wanita lebih banyak yang melakukan pengobatan daripada laki-laki. Sedangkan menurut Gupta [7], menyatakan bahwa wanita lebih sering yang melakukan pengobatan mandiri disebabkan karena mobilitas di luar rumah yang terbatas. Selain itu juga, menurut penelitian di Italia oleh Calamusa [15], menyatakan bahwa pengetahuan seseorang mengenai informasi yang terkait obat untuk swamedikasi yaitu perempuan lebih memiliki pengetahuan tentang obat dibandingkan laki-laki ditambah lagi perempuan lebih behati-hati dalam memilih obat dibandingkan laki-laki. Karakteristik berasarkan umur terbanyak yaitu 15 tahun (24,2\%). Menurut Notoadmodjo [16], usia merupakan hal yang sering diperhatikan, dimana semakin tua usia seseorang maka pengetahuan dan pengalaman yang dimiliki semakin baik sehingga mendorong seseorang untuk melakukan suatu tindakan pengobatan. Selain itu pada penelitian ini pengambilan sampel responden yang digunakan yaitu dengan cara simple random sampling sehingga setiap santriwati mempunyai kesempatan yang sama untuk menjadi responden. Karakteristik berdasarkan tingkat pendidikan paling banyak Madrasah Aliyah sebanyak $(47,0 \%)$. Hal ini terjadi karena sebagian besar dari populasi sedang menempuh pendidikan ditingkat MA. Selain itu pada penelitian ini pengambilan sampel responden yang digunakan yaitu dengan cara simple random sampling sehingga setiap santriwati mempunyai kesempatan yang sama untuk menjadi responden. Berdasarkan teori semakin tinggi tingkat pendidikan formal yang dimiliki seseorang maka semakin baik pula ditingkat pengetahuan serta kesadaran sikap seseorang dalam menyikapi penyakit yang dialaminya, akan tetapi seseorang yang memiliki tingkat pendidikan rendah tidak mutlak memiliki pengetahuan serta kesadaran sikap yang rendah, hal ini dikarenakan pengetahuan dapat diperoleh secara nonformal serta faktor lain yang dapat mempengaruhi [17].

Penyakit jamur kulit yang paling banyak dialami yaitu kutu air sebanyak $(62,1 \%)$ karena santriwati yang sering mencuci pakaian dan mencuci piring sehingga kaki sering terkena air yang mana daerah sekitar sela-sela jari kaki menjadi lembab sehingga menimbulkan bertumbuhnya jamur yang menyebabkan kutu air tersebut. Berdasarkan penelitian Hadi [18], Tinea pedis sering alami orang dewasa yang bekerja ditempat yang basah seperti tukang cuci dan jamur tumbuh pada kaki karena faktor kelembapan serta kebersihan kaki dapat menjadi 
faktor penyebab Tinea pedis karena lap atau handuk yang dipakai untuk mengeringkan kaki telah terkontaminasi spora jamur penyebab Tinea pedis. Jadi, meskipun kaki sudah dikeringkan tetapi handuk yang digunakan terkontaminasi jamur maka tidak bisa mencegah terjadinya Tinea pedis. Berdasarkan penelitian Bramono [19], menyatakan bahwa kelembapan dapat menjadi faktor penyebab infeksi jamur.

Obat yang sering digunakan responden yaitu salep $88 ®(48,5 \%)$ Berdasarkan hasil penelitian menunjukkan bahwa obat yang banyak digunakan oleh responden yaitu salep $88 \AA$ sebesar $48.5 \%$ untuk mengobati penyakit jamur kulit yang dialaminya. Berdasarkan komposisi salep $88 \circledR$ yang tertera pada label, salep ini mengandung asam salisilat, natrium benzoate dan sulfur praecipitatum. Obat tersebut memiliki khasiat untuk mengobati penyakit jamur kulit seperti panu, kutu air dan kadas/kurap. Cara penggunaan salep $88 \AA$ ini dengan mengoleskan salep pada daerah yang terinfeksi jamur sebanyak 3x sehari. Salep $88 \AA$ ini termasuk obat paten dengan golongan obat bebas yang bisa diperoleh di toko obat ataupun apotek. Hal ini diperkuat bahwa salep $88 \circledast$ dapat mengobati jamur kulit karena berdasarkan hasil penelitian Ulfa [20], bahwa asam salisilat dan asam benzoate dapat bermanfaat sebagai antifungi.

Tempat pembelian obat responden sebagian besar di apotek (72,7\%). Berdasarkan hasil penelitian menunjukkan bahwa sebagian besar responden memilih tempat pembelian obat di apotek yaitu sebesar $72.7 \%$. Berdasarkan hasil tersebut sesuai dengan penelitian sebelumnya bahwa didapatkan hasil yaitu sebagian besar responden melakukan pembelian obat di apotek [21]. Berdasarkan teori Zeenot [22] ditinjau dari kemudahan memperoleh produk obat, tidak sedikit orang lebih memilih kenyamanan untuk membeli obat di apotek dibandingkan dengan harus mengantri lebih lama di rumah sakit maupun klinik. Seseorang cenderung lebih memilih apotek karena lebih efektif dari segi biaya ataupun waktu yang dikeluarkan daripada periksa langsung ke dokter.

Sumber informasi untuk melakukan swamedikasi sebagian besar responden memperoleh informasi dari pengalaman pribadi dan keluarga $(83,3 \%)$. Berdasarkan hasil penelitian menunjukkan bahwa sebagian besar responden yaitu sebesar $83.3 \%$ memperoleh informasi dalam melakukan swamedikasi dari pengalaman pribadi dan keluarga. Berdasarkan hasil tersebut sesuai dengan penelitian sebelumnya bahwa didapatkan hasil yaitu sebagian besar responden melakukan pengobatan mandiri dikarenakan dari pengalaman terdahulu dalam penggunaan obat pribadi atau keluarga [23]. Menurut Notoatmodjo [16] keluarga itu salah satu faktor pendorong bagi seseorang dalam melakukan pengobatan. Menurut Mubarak [24], pengalaman adalah suatu hal yang diperoleh dimasa lalu. Dimana semakin banyak pengalaman seseorang, maka pengetahuan seseorang tersebut akan semakin bertambah.

\subsection{Tingkat Pengetahuan Responden Dalam Swamedikasi}

Tabel II. Tingkat Pengetahuan Swamedikasi (Pretest)

\begin{tabular}{cccc}
\hline \multirow{2}{*}{ Kelompok } & \multicolumn{3}{c}{ Kriteria } \\
\cline { 2 - 4 } & Kurang & Cukup & Baik \\
\hline Eksperimen & - & 5 & 28 \\
Kontrol & - & 2 & 31 \\
\hline Total & 0 & 7 & 59 \\
\hline Persentase & $0 \%$ & $10,6 \%$ & $89,4 \%$ \\
\hline
\end{tabular}

Berdasarkan tabel II dapat dilihat bahwa tingkat pengetahuan responden sebelum diberikan edukasi CBIA berkriteria baik sebesar $89,4 \%$. Pengukuran tingkat pengetahuan responden sebelum dilakukan edukasi dengan metode CBIA terkait dengan swamedikasi penyakit jamur kulit, terlebih dahulu dengan memberikan kuesioner pretest pada kelompok eksperimen maupun kelompok kontrol. Pretest ini dilakukan untuk melihat tingkat pengetahuan responden sebelum pemberian edukasi dengan metode CBIA terkait swamedikasi penyakit jamur kulit. Berdasarkan hasil penelitian menunjukkan bahwa tingkat pengetahuan santriwati sebelum diberikan edukasi CBIA pada kelompok eksperimen dan kelompok kontrol masuk 
dalam kategori baik dengan persentase sebanyak 89,4\%. Dari hasil tersebut tingkat pengetahuan sebelum diberikan edukasi sudah baik, hal ini mungkin dikarenakan karena pengalaman yang dimiliki santriwati.

Tabel III. Tingkat Pengetahuan Swamedikasi (Postest)

\begin{tabular}{cccc}
\hline \multirow{2}{*}{ Kelompok } & \multicolumn{3}{c}{ Kriteria } \\
\cline { 2 - 4 } Eksperimen & Kurang & Cukup & Baik \\
Kontrol & - & - & 33 \\
Total & - & 2 & 31 \\
\hline Persentase & 0 & 2 & 64 \\
\hline
\end{tabular}

Berdasarkan tabel III dapat dilihat bahwa tingkat pengetahuan responden sesudah diberikan edukasi CBIA berkriteria baik sebesar $89,4 \%$. Pengukuran tingkat pengetahuan sesudah diberikan edukasi dengan pemberian kuesioner posttest sehari setelah pemberian pretest dan edukasi dengan metode CBIA pada kelompok eksperimen maupun kelompok kontrol. Postest ini diberikan dengan tujuan untuk mengetahui apakah ada peningkatan pengetahuan responden terkait swamedikasi penyakit jamur kulit setelah diberikan edukasi dengan metode CBIA yang menggunakan media leaflet dengan alat peraga berupa paket obat atau contoh obat. Berdasarkan hasil penelitian menunjukkan bahwa tingkat pengetahuan santriwati sesudah diberikan edukasi CBIA pada kelompok eksperimen dan kelompok kontrol masuk dalam kategori baik dengan persentase sebanyak 96,97\%. Dari hasil tersebut berarti ada peningkatan pengetahuan sebelum dan sesudah diberikan edukasi.

\subsection{Pengaruh Edukasi dengan Metode CBIA Terhadap Pengetahuan Swamedikasi Penyakit Jamur Kulit Pada Santriwati}

Tabel IV. Hasil Uji Wilcoxon signed rank

\begin{tabular}{ccccccccc}
\hline \multirow{2}{*}{ Kelompok } & \multicolumn{3}{c}{ Kriteria pretest } & \multicolumn{3}{c}{ Kriteria posttest } & \multirow{2}{*}{ Mean } & $\boldsymbol{p}$ - \\
\cline { 2 - 8 } & Kurang & Cukup & Baik & Kurang & Cukup & Baik & & value \\
\hline Eksperimen & - & 5 & 28 & - & - & 33 & 17,00 & 0,000 \\
Kontrol & - & 2 & 31 & - & 2 & 31 & 10,70 & 0,086 \\
\hline Total & $0 \%$ & $10,6 \%$ & $89,4 \%$ & $0 \%$ & $3,03 \%$ & $96,97 \%$ & & \\
\hline
\end{tabular}

Berdasarkan tabel IV dapat dilihat bahwa hasil dari nilai signifikasi pada kelompok eksperimen sebesar 0,000 ( $p$ value $<0,05$ ). Sedangkan nilai signifikasi pada kelompok kontrol sebesar 0,086 ( $p$ value $>0,05$ ). Pengujian Wilcoxon ini untuk mengetahui perbedaan tingkat pengetahuan sebelum dan sesudah diberikan edukasi pada kelompok eksperimen dan kelompok kontrol menggunakan pretest-postest kelompok eksperimen dan kelompok kontrol dengan melihat nilai $p$-value. Berdasarkan hasil uji Wilcoxon menunjukkan nilai signifikasi dari kelompok eksperimen sebesar 0,000 ( $p$-value $<0,05)$ maka dapat dikatakan terdapat perbedaan pengetahuan swamedikasi penyakit jamur kulit antara sebelum dan setelah diberikan edukasi CBIA. Hal ini dikarenakan adanya pemberian edukasi kepada santriwati terkait informasi swamedikasi penyakit jamur kulit dengan menggunakan metode edukasi CBIA. Dimana metode ini melibatkan langsung subjek sehingga responden dapat berperan aktif dalam pencarian informasi dengan melihat, mendengar, menulis dan mengevaluasi informasi dari leaflet dan paket obat yang telah diberikan. Sedangkan nilai signifikasi pada kelompok kontrol sebesar 0,086 ( $p$-value>0,05) maka tidak terdapat perbedaan pengetahuan. Hal ini dikarenakan tidak adanya pemberian edukasi dengan metode CBIA.

Uji selanjutnya dengan uji Mann-Whitney, digunakan uji ini karena data tidak terdistribusi normal. Pengujian Mann-Whitney ini untuk menjawab hipotesis dengan melihat adanya pengaruh setelah pemberian edukasi terhadap tingkat pengetahuan responden pada kelompok kontrol dan kelompok eksperimen. 
Tabel V. Hasil Uji Mann-Whitney

\begin{tabular}{cccccc}
\hline \multirow{2}{*}{ Kategori } & \multicolumn{2}{c}{ Kelompok Eksperimen } & \multicolumn{2}{c}{ Kelompok Kontrol } & \multirow{2}{*}{$\boldsymbol{P}$-value } \\
\cline { 2 - 5 } & $\mathbf{N}$ & $\boldsymbol{\%}$ & $\mathbf{N}$ & $\boldsymbol{\%}$ & \\
\hline Kurang & - & 0 & - & 0 & \\
Cukup & - & 0 & 2 & 3,03 & 0,000 \\
Baik & 33 & 50 & 31 & 46,97 & \\
\hline
\end{tabular}

Berdasarkan tabel $\mathrm{V}$ dapat dilihat nilai $p$-value yaitu $0,000(\mathrm{p}<0,05)$ maka dapat dikatakan terdapat perbedaan antara kelompok eksperimen dan kelompok kontrol. Berdasarkan hasil uji Mann-Whitney menunjukkan nilai $p$-value yaitu 0,000 ( $p$-value < 0,05) maka dapat dikatakan terdapat perbedaan antara kelompok eksperimen dan kelompok kontrol. Jadi, hasil penelitian ini sesuai dengan hipotesis yang mana terdapat adanya pengaruh setelah dilakukan edukasi dengan metode CBIA terhadap tingkat pengetahuan swamedikasi penyakit jamur kulit pada santriwati. Hasil ini sesuai dengan teori yang dikemukakan oleh Suryawati [25], bagian farmakologi klinik Universitas Gajah Mada Yogyakarta yang merupakan pencetus metode CBIA pada tahun 1993 bahwa metode CBIA terbukti sangat efektif dalam meningkatkan pengetahuan. Hasil penelitian juga sejalan dengan penelitian yang dilakukan Musdalipah [26], menunjukkan adanya pengaruh yang bermakna pemberian metode CBIA terhadap peningkatan pengetahuan siswa SMA Negeri 1 Kendari tentang swamedikasi dengan nilai p-value 0,029. Menurut Witri [27], menunjukkan bahwa metode CBIA berpengaruh signifikan terhadap pengetahuan tentang informasi obat salesma dengan nilai probabilitas 0,000. Berdasarkan keempat penelitian sebelumnya menunjukkan bahwa edukasi dengan metode CBIA efektif dalam meningkatkan pengetahuan dalam swamedikasi. Peningkatan pengetahuan ini tentunya menjadi dampak positif bagi dunia khususnya pada sektor pelayanan kesehatan masyarakat. Manfaat dari edukasi dengan metode CBIA ini yaitu untuk menambah pengetahuan terkait pentingnya menggunakan obat dengan benar, meningkatkan kemandirian dan perubahan perilaku responden dalam pemilihan dan penggunaan obat dengan benar yang nantinya meningkatkan penggunaan obat secara rasional.

\section{KESIMPULAN}

Pemberian edukasi dengan metode CBIA efektif berpengaruh terhadap tingkat pengetahuan swamedikasi jamur kulit pada santriwati Pondok Pesantren Al-Mubarok Medono Pekalongan dengan nilai $p$-value pada uji mann-whitney sebesar $0,000(p<0,05)$.

\section{DAFTAR PUSTAKA}

[1] Rahman, M. Afif Auliya., Jusak., \& Erwin S, "Sistem Pakar Identifikasi Penyakit Jamur Kulit Pada Manusia Menggunakan Metode Certainty Factor", JSIKA , Vol 5 (3), 2016, [Online]

[2] Harahap, N.A, Khairunnisa' \& Juanita T, "Tingkat Pegetahuan Pasien Rasionalitas Swamedikasi di Tiga Apotek Kota Panyabungan”, Skripsi, 2015, Medan : Fakultas Farmasi Universitas Sumatera Utara.

[3] Amalia, Via, "Hubungan Persepsi Tentang Penyakit Jamur Kulit Terhadap Perilaku Swamedikasi Di Kelurahan Panjang Wetan Kota Pekalongan Tahun 2020”, Skripsi, 2020, Universitas Muhammadiyah Pekajangan Pekalongan, Pekalongan.

[4] Fuaddah, A.T, "Description of Self-Medication Behavior In Community of Subdistrict Purbalingga, District Purbalingga", Jurnal Kesehatan Masyarakat (e-Journal) FKM Undip, Vol 3 (1), 2015, [Online]

[5] Adhikary, M., Tiwari, P., Singh, S., \& Karoo, C, "Study of selfmedication practices and its determinant among college students of Delhi University North Campus New Delhi, India", 
International Journal of Medical Science and Public Health, Vol 3(4), hal 406-409, 2014, [Online]

[6] Badan Pusat Statistik, "Statistik Indonesia", 2016, Jakarta: BPS.

[7] Gupta, P., Bobhate, P., dan Shirivastava, S, "Determinats of Self Medication Practise in an Urban Slum Community", Asian Journal Pharmaceutical and Clinical Research. 4(3): 54-57. India, 2011, [Online]

[8] Sugiyono, "Metode Penelitian Kuantitatif Kualitatif dan R \& D", Cetakan XVIII, 2013, Bandung: Alfabeta.

[9] Priyatno. D, "SPSS Handbook : Analisis Data, Olah Data \& Penyelesaian Kasus-Kasus Statistik", 2016, Yogyakarta: Mediakom.

[10] Sugiyono, "Statistik untuk Penelitian", 2017, Bandung: Alfabeta.

[11] Hastono, Sutanto Priyo, "Analisa Data Kesehatan", 2013, Jakarta: Fakultas Kesehatan Masyarakat Universitas Indonesia.

[12] Ghozali, "Aplikasi Analisis Multivariat dengan Program IBM SPSS 25", 2018, Semarang: Universitas Diponegoro.

[13] Utomo, "Eksplorasi Data dan Analisis Regresi dengan SPSS", 2012, Surakarta: Muhammadiyah University Press.

[14] Cho, et al, "The Factor Contributing to Expenditures on Over-the Counter Drugs in South Korea", Public Health. Seul National University, Vol. 05: 147-151, 2013, [Online]

[15] Calamusa, A., Di Marzio, A., Cristofani, R., Arrighetti, P., Santaniello, V., Alfani, S., \& Carducci, A, "Factors that Influence Italian Consumers Understanding of over-the-counter Medicinies and Risk Perception", Patient Education and Counseling, Vol. 87(3), 395-401, 2012, [Online]

[16] Notoatmodjo, "Kesehatan Masyarakat", 2010, Jakarta: PT Rineka Cipta.

[17] Notoatmodjo, "Pendidikan dan Perilaku Kesehatan", 2012, Jakarta: PT Rineka Cipta.

[18] Hadi, S dan Supardi, "Revitalization Strategy for Small and Medium Enterprises after Corona Virus Disease Pandemic (Covid-19) in Yogyakarta Xi'an Jianzhu Keji Daxue Xuebao", Journal of Xi' an University of Architecture \& Tecnology, 2020, [Online]

[19] Bramono, K, "Ilmu Penyakit Kulit dan Kelamin", 2016, Jakarta : Badan Penerbit FKUI.

[20] Ulfa, A.M., \& Nofita, "Analisa Asam Benzoate dan Asam Salisilat Dalam Obat Panu Sediaan Cair”, Jurnal Kebidanan, Vol2 (2), halaman 51-59, 2016, [Online]

[21] Syarifah, Nailatul, "Tingkat Pengetahuan dan Sikap Terhadap Tindakan Pengobatan Mandiri Penyakit Kutu Air", Skripsi, 2020, Universitas Muhammadiyah Pekajangan Pekalongan, Pekalongan.

[22] Zeenot, S, "Pengelolaan \& Penggunaan Obat Wajib Apotek", 2013, Yogyakarta: D-Medika

[23] Harahap, N.A, Khairunnisa' \& Juanita T, "Tingkat Pegetahuan Pasien Rasionalitas Swamedikasi di Tiga Apotek Kota Panyabungan”, Jurnal Farmasi \& Kliniks, Vol 10 (01), 972975, 2017, [Online]

[24] Mubarak, Wahit Iqbal, "Promosi Kesehatan untuk Kebidanan”, 2011, Jakarta: Salemba Medika

[25] Suryawati, S, "Meningkatkan Keterampilan Memilih Obat denganMetodeCBIA", 2012, [Online], Available: http:www.suryawati.com/downloads.php?cat=5, diakses tanggal 25 April 2021.

[26] Musdalipah., Daud N.S., Fauziah Y \& Karmilah, "Peningkatan Pengetahuan Siswa SMA Negeri 1 Kendari Tentang Swamedikasi dengan Metode CBIA (Cara Belajar Insan Aktif)", JMM-Jurnal Mayarakat Merdeka, Vol 1 (01), 2018, [Online]

[27] Witri, Wijayanti A., \& Mawardi M.I, "Pengaruh Metode CBIA (Cra Belajar Insan Aktif) Terhadap Pengetahuan Informasi Obat Salesma Pada Anggota Karng Taruna Dusun Wanujoyo Lor Srimartani Piyungan Bantul", Jurnal Ilmu Kesehatan Bhakti Setya Medika, Vol. 2, 2017, [Online] 